\title{
COMMENTARY
}

\section{Zika Virus and Microcephaly: Challenges in Brazil}

\author{
Antonio de Pádua Serafim ${ }^{1,2,}$, Juliana Emy Yokomizo ${ }^{1}$ and Daniel Martins de Barros ${ }^{3}$ \\ ${ }^{1}$ Neuropsychology Unit, Department and Institute of Psychiatry, School of Medicine, University of São Paulo, \\ Brazil \\ ${ }^{2}$ Department of Health Psychology, Methodist University of São Paulo, São Bernardo do Campo (SP), Brazil \\ ${ }^{3}$ Department and Institute of Psychiatry, School of Medicine, University of São Paulo, Brazil
}

The current epidemic scenario of the Zika Virus (ZIKV) in several countries has been raising important discussion regarding the real impact of its pathological features [1, 2]. Data from the World Health Organization (WHO) indicate that the first cases of this Zika outbreak was reported last year and spread to 32 countries, most of them located on the American continent. [3] In some countries such as Brazil, the number of ZIKV cases is worrisome. Data from the Ministry of Health [4] show that 22 of 26 Brazilian states have had at least one case of laboratorial confirmation of the disease.

There are many ongoing studies that attempt to identify possible symptoms associated with ZIKV. Some findings suggest that the infection could trigger Guillain-Barré Syndrome, an autoimmune condition which may lead to respiratory failure caused by progressive muscle weakness [5]. Ocular lesions and optic nerve abnormalities, joint contractures and scalp rugae may also be related to ZIKV infection $[6 ; 7,8]$.

One of the biggest concerns regarding Zika is maternal-fetal transmission that has been already been documented [6], and confirmed as having a causal relation with neonatal microcephaly and other neurological defects, such as brain atrophy, ventricular enlargement and intracranial calcifications [7, 9].

In Brazil, where the present outbreak first occurred, the incidence of microcephaly was around 156 births per year between 2010 to 2014; during 2015 until early 2016 , there has been a total of 6,158 reported cases. Thus, the cases of microcephaly increased approximately 20 -fold, being most reported in the Northeast region of the country [4]. Current data shows

*Address correspondence to this author at the Rua Dr. Ovidio Pires de Campos, 785 - Cerqueira Cesar, 05403-903 - Sao Paulo, SP, Brazil; Tel: + 55 11 26617929; Fax: + 5511 26617929; E-mail: a.serafim@hc.fm.usp.br a rate of $99.7 / 100,000$ for live births. Even if taking into account the possibility that the previous incidence rates were due to mis-notification, it remains that from November 2015 to February 2016, 5,640 cases of suspected microcephaly were reported. Of this total, 1533 cases were submitted to molecular and imaging investigation. Results showed that $38 \%(n=583)$ of the investigated cases had association with ZIKV through genetic material $(n=67)$ or brain imaging tests $(n=516)$ [3]. Now proven that the epidemic leads to microcephaly, it is urgent to foresee probable scenarios and assemble efforts to deal with them.

Head circumference $(\mathrm{HC})$ is one tool for screening microcephaly [2]. Data from the World Health Organization recognizes normal $\mathrm{HC}$ as around 34.5 centimeters in the $37^{\text {th }}$ week of pregnancy [2]. There is no international consensus to define microcephaly in terms of $\mathrm{HC}$, however, and some sources use a definition of 2-4 standard deviations below the mean ( $\mathrm{HC}-2,-3$ or -4$)$, or $\mathrm{HC}$ below the $5^{\text {th }}$ or the $3^{\text {rd }}$ percentile [10]. On March 10, 2016, the Brazilian Ministry of Health determined necessary formal notification for all cases with an' $\mathrm{HC}$ lesser than or equal to $32 \mathrm{~cm}$ [11].

In any event, over next two decades, the affected cohort will face "vital challenges", including those involving neuropsychomotor development stages, literacy and professional preparation. We cannot wait to take adequate measures, since early intervention may change the outcome: while $50 \%$ of children with $\mathrm{HC}-3$ had mental retardation at age seven, for children with HC -2, socio-economic status somehow reduced the incidence of this diagnostic [12]. And probably these cases may need additional help for apparently simple achievements. The severity of the microcephaly might also lead to different correlated symptoms. Seizures, sensorial problems, cerebral palsy or other 
developmental abilities might be present in severe microcephaly [10].

An additional challenge is proper diagnosis of children with this condition: although rare, there are dozens of causes of small $\mathrm{HC}$, be they genetic, toxic or infectious, and one cannot assume that all cases of microcephaly are due to ZIKV, but should instead carefully investigate other causes to properly investigate each case [13].

Therefore, we urge that public health programs should be developed in order to offer adequate possibilities for diagnostic and care, considering the large future number of young people with some kind of neurological and/ or cognitive impairment. It is probable that less severe degrees of microcephaly (i.e., head circumference closer to the normal range) could benefit most from early stimulation; however, any intellectual and cognitive intervention must be done early, as little is known about normal acquisition without a proper treatment.

Considering this scenario, neuropsychological comprehension will be crucial, which includes intervention both with children and also with the parents and relatives, through support and offering of psychoeducational information. In our point of view, this is the gap in the whole discussion: despite the relevance of searching for causes and controlling the zika outbreak, international effort should be undertaken to prepare protocols for etiological diagnostics and early intervention programs, aiming to stimulate cognitive development and minimize the effects present in new cases of microcephaly.

\section{REFERENCES}

[1] Lucey DR, Gostin LO. The Emerging Zika Pandemic: Enhancing Preparedness. JAMA 2016; 315(9): 865-6. http://dx.doi.org/10.1001/jama.2016.0904
[2] Victora CG, Schuler-Faccini L, Matijasevich A, Ribeiro E, Pessoa A, Barros FC. Microcephaly in Brazil: how to interpret reported numbers? Lancet 2016; 13: 387(10019):621-4. doi: 10.1016/S0140-6736(16)00273-7.

[3] World Health Organization. Zika situation report 10 March 2016. Available from: http://www.who.int/emergencies/Zikavirus/situation-report/10-march-2016/en.

[4] Brasil, Ministério da Saúde. Centro de Operações de Emergências em Saúde Pública sobre Microcefalias. Monitoramento de Casos de Microcefalia no Brasil. Informe epidemiológico 14: Ministério da Saúde, Brasília (2016) (in Portuguese). Available from: http://www.saude.gov.br/svs.

[5] Malkki H. CNS infections: Zika virus infection could trigger Guillain-Barre syndrome. Nature Reviews Neurology 2016. http://dx.doi.org/10.1038/nrneurol.2016.30

[6] Besnard M, Lastere S, Teissier A, Cao-Lormeau V, Musso D. Evidence of perinatal transmission of Zika virus, French Polynesia, December 2013 and February 2014. Euro Surveill 2014; 19: 20751.

http://dx.doi.org/10.2807/1560-7917.ES2014.19.13.20751

[7] de Paula Freitas B, de Oliveira Dias J, Prazeres J, et al. Ocular Findings in Infants With Microcephaly Associated With Presumed Zika Virus Congenital Infection in Salvador, Brazil. JAMA Ophthalmol. Published online February 09, 2016.

http://dx.doi.org/10.1001/jamaophthalmol.2016.0267

[8] Oliveira Melo AS, Malinger G, Ximenes R, Szejnfeld PO, Alves Sampaio S, Bispo de Filippis AM. Zika virus intrauterine infection causes fetal brain abnormality and microcephaly: tip of the iceberg? Ultrasound Obstet Gynecol 2016; 47: 6-7. http://dx.doi.org/10.1002/uog.15831

[9] Meaney-Delman D, et al. Zika virus and pregnancy: what obstetric health care providers need to know. Obstetrics \& Gynecology 2016; 127(4): 642-648.

http://dx.doi.org/10.1097/AOG.0000000000001378

[10] Brasil Ministério da Saúde. Secretaria de Vigilância em Saúde. Departamento de Vigilância das Doenças Transmissíveis. Protocolo de vigilância e resposta à ocorrência de microcefalia relacionada à infecção pelo vírus Zika. Brasília: Ministério da Saúde, 2016. (in Portuguese)

[11] Rasmussen SA, Jamieson DJ, Honein MA, Petersen LR. Zika Virus and Birth Defects - Reviewing the Evidence for Causality. N Engl J Med 2016. http://dx.doi.org/10.1056/NEJMsr1604338

[12] Dolk $\mathrm{H}$. The predictive value of microcephaly during the first year of life for mental retardation at seven years. Dev Med Child Neurol 1991; 33(11): 974-83. http://dx.doi.org/10.1111/j.1469-8749.1991.tb14813.x

[13] Abuelo D. Microcephaly syndromes. Semin Pediatr Neurol 2007; 14(3): 118-27. Review. http://dx.doi.org/10.1016/i.spen.2007.07.003

DOI: http://dx.doi.org/10.6000/2292-2598.2016.04.02.1

(C) 2016 Serafim et al.; Licensee Lifescience Global.

This is an open access article licensed under the terms of the Creative Commons Attribution Non-Commercial License (http://creativecommons.org/licenses/by-nc/3.0/) which permits unrestricted, non-commercial use, distribution and reproduction in any medium, provided the work is properly cited. 